Article

\title{
Movements and Habitat Use of Dolphinfish (Coryphaena hippurus) in the East China Sea
}

\author{
Shian-Jhong Lin ${ }^{1,2}$, Wei-Chuan Chiang ${ }^{1, *}$, Michael K. Musyl ${ }^{3} \oplus$, Sheng-Ping Wang ${ }^{2}$, \\ Nan-Jay Su ${ }^{2}{ }^{\oplus}$, Qi-Xuan Chang ${ }^{1}$, Yuan-Shing Ho ${ }^{1}$, Itsumi Nakamura ${ }^{4}$, Chen-Te Tseng ${ }^{5}$ and \\ Ryo Kawabe ${ }^{4}$ \\ 1 Eastern Marine Biology Research Center, Fisheries Research Institute, 22 Wuchuan Road, Taitung, \\ Chenggong 961, Taiwan; 20231001@mail.ntou.edu.tw (S.-J.L.); chchang03@mail.tfrin.gov.tw (Q.-X.C.); \\ yuanho18@gmail.com (Y.-S.H.) \\ 2 Department of Environmental Biology and Fishery Science, National Taiwan Ocean University, \\ 2 Beining Road, Jhongjheng District, Keelung 202, Taiwan; wsp@mail.ntou.edu.tw (S.-P.W.); \\ nanjay@ntou.edu.tw (N.-J.S.) \\ 3 Pelagic Research Group LLC, P.O. Box 10243, Honolulu, HI 96816, USA; Michael.Musyl@gmail.com \\ 4 Institute for East China Sea Research, Organization for Marine Science and Technology, Nagasaki University, \\ 551-7 Taira-Machi, Nagasaki, Nagasaki 851-2213, Japan; itsumola@gmail.com (I.N.); \\ flatfish68@gmail.com (R.K.) \\ 5 Fisheries Research Institute, No. 199, Hou-Ih Rd., Jhongjheng District, Keelung City 202, Taiwan; \\ cttseng@mail.tfrin.gov.tw \\ * Correspondence: wcchiang@mail.tfrin.gov.tw
}

Received: 14 May 2020; Accepted: 14 July 2020; Published: 18 July 2020

check for updates

\begin{abstract}
To refine the regional and global stock and ecological assessments of dolphinfish in fisheries, it is necessary to have information on the species habitat use, fisheries interaction, migration corridors, and on changes in spatial-temporal patterns over their ontogeny. In order to inform management, pop-up satellite archival tags (PSATs) were deployed on dolphinfish (Coryphaena hippurus) in the Northern East China Sea to get data on the movement patterns and habitat utilization of this species in this location. During October-November 2018, four dolphinfish (94-102 cm fork length) were captured by set-nets and PSAT tagged. Tagged dolphinfish retained PSATs for 5-31 days-at-liberty (total 69 days) and linear dispersion from deployment to pop-up locations ranged from 63 to $204 \mathrm{~km}$. According to most probable tracks, tagged fish made primarily northward movements. Tagged fish reached depths of $\sim 94 \mathrm{~m}$ and experienced ambient temperatures from 17.8 to $23^{\circ} \mathrm{C}$. Movements appeared to be limited by a $3{ }^{\circ} \mathrm{C}$ change relative to sea surface temperature (SST) and were confined to the mixed-layer. Diel diving patterns indicated dolphinfish spent $>80 \%$ of daytime activity and $40 \%$ of nighttime activity near the surface, where variability in diving patterns was more pronounced. The vertical diving patterns showed pronounced changes during dawn and dusk, where dolphinfish mirrored the movements of diel migrating prey organisms. Our preliminary results provide vertical distribution patterns of dolphinfish in a location that supports important fisheries. This information will be useful for management to develop stock assessments which support the sustainable use of this species.
\end{abstract}

Keywords: fisheries management; horizontal movements; pop-up satellite archival tags (PSATs); spatial-temporal; stock assessments; thermal niche; vertical habitat

\section{Introduction}

Epipelagic dolphinfish are globally distributed in tropical and warm-temperate environments that extend from Nova Scotia, Canada to the Tasman Sea [1,2], covering $\sim 46^{\circ} \mathrm{N}$ to $38^{\circ} \mathrm{S}[3-5]$. 
Dolphinfish migrate in large numbers and traverse different fisheries management areas [6-8] but capture rates and abundance appear to be limited by $20^{\circ} \mathrm{C}$ isotherms [3], sea surface temperature (SST), and seasonal changes in resources available for prey [4,9-12]. Dolphinfish are predators, grow fast [11,13], mature early [13,14], and are a high-value food for humans [15,16]. Dolphinfish support commercial, artisanal, and sport fisheries in the Caribbean, Southeastern United States, East Africa, Hawaii, China, Taiwan, Japan, and many other countries [6,15-17].

The global catch of dolphinfish reaches $3600-12,000 \mathrm{mt}$, with the Pacific Ocean producing $77 \%$, the Atlantic Ocean 14\%, and the Indian Ocean 9\% of the global catch. In the Pacific Ocean, the Southeast Pacific (FAO area 87), and the Northwest Pacific (FAO area 61) accounts for an estimated $65 \%$ and $22 \%$ of the catch, respectively (http://www.fao.org/fishery/species/3130/en). The abundant resources of the Kuroshio Current in the Northwest Pacific Ocean support important fisheries in Taiwan and Japan [17]. The current genetic stock structure of dolphinfish in the Pacific suggests a single panmitic population $[18,19]$ and populations are managed as a single stock in the Kuroshio Current from Taiwan and Japan [20]. Based on limited information from life-history characteristics, the Pacific dolphinfish stocks appear to be in good condition [21], but there is high uncertainty because stock assessments have not been conducted [21]. Dolphinfish landings in Taiwan are cyclic with peak fluctuations, but catches have declined in coastal areas in recent decades [22]. However, these cycles may be correlated with oceanographic conditions on recruitment patterns [22].

High exploitation rates and the commercial importance of dolphinfish warrant the need for better baseline knowledge of life-history traits and behaviors in order to ensure sustainable fisheries management [23]. Understanding the movement and habitat use of dolphinfish is critical for the regional management of fisheries. This information can help to predict changes in the distribution of dolphinfish during varying temperature regimes and to implement bycatch reduction regulations if necessary (e.g., depth limit of gear, closed seasons, and protected areas). The first electronic tagging study on dolphinfish in the Northwestern Pacific Ocean was conducted in the East China Sea [24] and it demonstrated that swimming behaviors were associated with vertical temperature gradients and the structure of the mixed-layer. Ample research has now confirmed that pop-up satellite archival tags (PSATs) are an effective fishery-independent tool for recording horizontal and vertical movements of pelagic species [25]. The first PSAT study on dolphinfish in Taiwan [25] reported primarily north-south movements that were influenced by season.

Although dolphinfish have been studied with PSATs in the Northwestern Pacific Ocean [24,26,27], there are no quantitative studies that have investigated the horizontal and vertical movement patterns in the Northern East China Sea. The objective of this study is to explore movement behaviors, thermal niche, and distribution of fish in this region, compared with those found in Southeastern Taiwan. These data will provide fishery-independent information on dolphinfish behavior at different spatial scales to help managers sustainably manage dolphinfish fisheries across different jurisdictional boundaries.

\section{Materials and Methods}

\subsection{Satellite Telemetry Data}

PSATs (models X-tag and high rate (HR) X-tag) made by Microwave Telemetry, Columbia, MD, USA were deployed on dolphinfish in the Northern East China Sea. The PSATs recorded depth, temperature, and ambient light levels, and were programmed to release 8 months (for X-tag) and 1 month (for HR X-tag) after deployment. Depth ranged from 0 to $1250 \mathrm{~m}$ (X-tag resolution: $0.34-5.4 \mathrm{~m}$, HR X-tag resolution: $1.34 \mathrm{~m}$ ) and temperature ranged from -4 to $40{ }^{\circ} \mathrm{C}$ (resolution: $0.16-0.23{ }^{\circ} \mathrm{C}$ ). The PSATs had variable memory capacity and the X-tag collected data at $15 \mathrm{~min}$ intervals during the first 4 months, 30 min intervals at $4-8$ months, and 60 min intervals at $>8$ months. The HR X-tag recorded data every 4 min during the 30-day mission. Following pop-off, archived depth, temperature, and light intensity data were transmitted to Argos. It was not possible to estimate individual tracks because the HR X-tag does not record light intensity. 


\subsection{Tagging Operation}

A total of four dolphinfish were captured with set-nets from a complex in Southwest Japan (Figure 1, Table 1). Fish were hoisted on deck to a platform using nets and placed on a stretcher. Next, during PSAT affixation, a wet towel was placed over the eyes and a seawater hose was inserted into the mouth of the fish to calm it. To prevent infection, tag heads and tethers were disinfected with alcohol and bacitracin-neomycin ointment was applied to the tag head before inserting it into the dorsal musculature.

Each PSAT was rigged with fluorocarbon tethers $(200 \mathrm{lb}$. test) stainless steel crimps, nylon umbrella tag heads, and stainless steel ball-bearing swivels (Sampo no. 5, Barneveld, NY, USA) were placed $\sim 6 \mathrm{~cm}$ from the tag head to reduce torque and precession. Fork length (FL) was measured to the nearest centimeter.

\subsection{Data Analysis}

Analytical procedures and data partitioning followed methods in [26,28]. Briefly, raw light-based geolocations were provided by the manufacturer [29] and most probable tracks (MPTs) were determined using an SST-corrected (unscented) Kalman filter [30,31]. Local times of sunrise and sunset were determined from the MPTs and data were partitioned into daytime and nighttime. The data distributions were tested for normality using Kolmogorov-Smirnov tests and found to be non-normally distributed. Therefore, differences in depth and temperature between daytime and nighttime were tested by using non-parametric Mann-Whitney W-tests [26,32]. Distribution patterns were tested by examining movements relative to changes in $\triangle \mathrm{SST}$ (i.e., temperature differences from daily mean sea surface temperature) $[28,33,34]$. For comparison, the $\Delta$ SST analysis also included six tags from a previous study [26]. For presentation, depth and temperature data were aggregated into $5 \mathrm{~m}$ and $1{ }^{\circ} \mathrm{C}$ intervals, respectively. To look for movement patterns in different areas, the greatest vertical distances between cumulative distribution functions $\left(\mathrm{D}_{\mathrm{N}}\right)$ among tags (from two-sample Kolmogorov-Smirnov tests) were formatted into an input matrix for UPGMA (unweighted pair-group method using arithmetic averages) clustering using Euclidean distances [28]. Dolphinfish tagging data from the previous [26] and the present study were used in the cluster analysis.

\section{Results}

PSATs were deployed on four dolphinfish (94-102 cm FL) with the deployment details, retention periods, and data return rates provided in Figure 1 and Table 1 . Straight-line distances from deployment to pop-up locations ranged from 63 to $204 \mathrm{~km}$ with speeds of 3.95-12.4 km/day (Table 1). According to the MPTs, fish \#64585 moved eastwards and then exhibited a northward movement along the coast, and fish \#64587 moved northwards from the tagging area to a point near Tsushima Island (Figure 1). Straight-line movement suggests \#45912 moved northwards (Figure 1) until it reached the 30-day programmed pop-up date near the Japan Sea. Fish \#45914 moved westwards for five days-at-liberty after which the tag detached (Figure 1). 
Table 1. Details of tag deployments, pop-up and percentage data received from pop-up satellite archival tags (PSATs) deployed on dolphinfish in the Tachiura set-net (Northern East China Sea). DAL = days-at-liberty; the straight-line distance was measured from deployment to pop-up locations. Data return rate represents the average of depth, temperature, and geolocation data (see text for explanation [29]).

\begin{tabular}{|c|c|c|c|c|c|c|c|c|c|}
\hline PSAT\# & FL $(\mathrm{cm})$ & Deployment Date & Reporting Date & $\begin{array}{c}\text { DAL } \\
\text { (Days) }\end{array}$ & $\begin{array}{c}\text { Straight-Line } \\
\text { Distance } \\
(\mathbf{k m})\end{array}$ & $\begin{array}{c}\text { Average Daily } \\
\text { Displacements } \\
\text { (km/Day) }\end{array}$ & $\begin{array}{c}\text { Data Return } \\
\text { Rate (\%) }\end{array}$ & Pop-off Reason ${ }^{1}$ & Tag Type \\
\hline 64585 & 96 & 31 October 2018 & 20 November 2018 & 21 & 82.92 & 3.95 & 77 & Constant Pressure & X-tag \\
\hline 64587 & 101 & 1 November 2018 & 12 November 2018 & 12 & 97.27 & 8.4 & 89 & Constant Pressure & X-tag \\
\hline 45912 & 94 & 1 November 2018 & 1 December 2018 & 31 & 203.67 & 6.57 & 48 & Memory Full & HR X-tag \\
\hline 45914 & 102 & 1 November 2018 & 5 November 2018 & 5 & 62.64 & 12.4 & 36 & Constant Pressure & HR X-tag \\
\hline
\end{tabular}

${ }^{1}$ Constant Pressure indicates a prematurely detached, floating tag and Memory Full indicates a tag that reached the programmed pop-up date. 


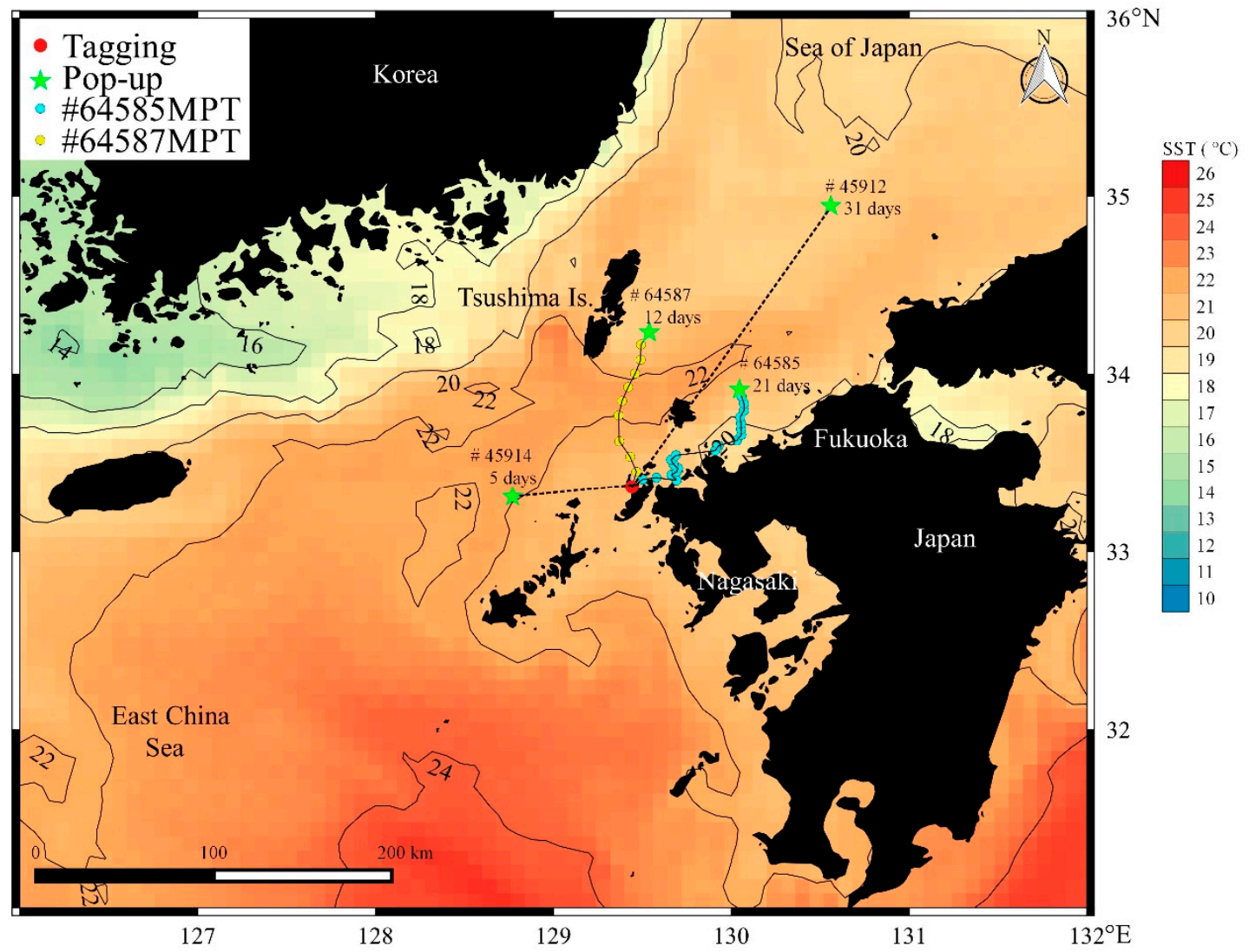

Figure 1. Deployment and pop-up locations for dolphinfish carrying pop-up satellite archival tags. Most probable tracks (MPTs) for \#64585 and \#64587. Dashed lines represent straight-line movements for \#45912 and \#45914. Sea surface temperature (SST) contours from APDRC data (Asia-Pacific Data Research Center, http://apdrc.soest.hawaii.edu/) are shown.

The maximum depth attained was $94 \mathrm{~m}$ (Figure 2), with temperatures ranging from 17.78 to $23.05^{\circ} \mathrm{C}$. Dolphinfish exhibited significant diel movement patterns $(p<0.05$, Figure 3$)$ and spent more than $80 \%\left(20-22{ }^{\circ} \mathrm{C}\right)$ of time near the surface $(<5 \mathrm{~m})$ during daytime and $40 \%$ of their time at the surface during nighttime. More extensive and variable vertical excursions occurred at nighttime but were confined to the mixed-layer depth (MLD) above $20^{\circ} \mathrm{C}$ and all fish exhibited pronounced crepuscular transitions (Figure 4). Figure 5 shows daily SST, minimum temperature, and maximum depth experienced by the tagged fish. Fish \#45912 experienced daily temperatures that significantly decreased over time as it moved to a different water mass at higher latitudes (Figure 5). 


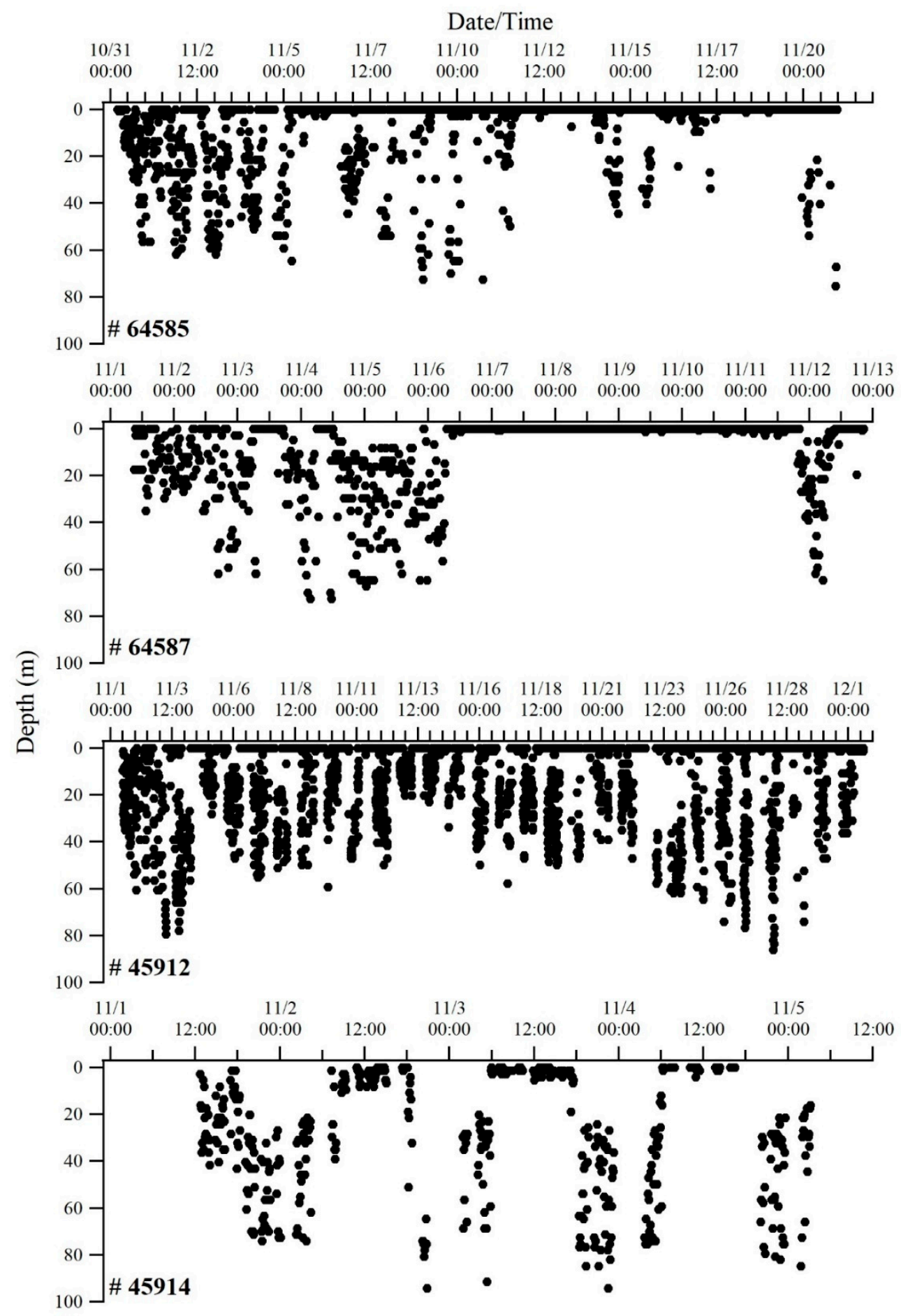

Figure 2. Time-depth series of dolphinfish tagged in the Northern East China Sea. 


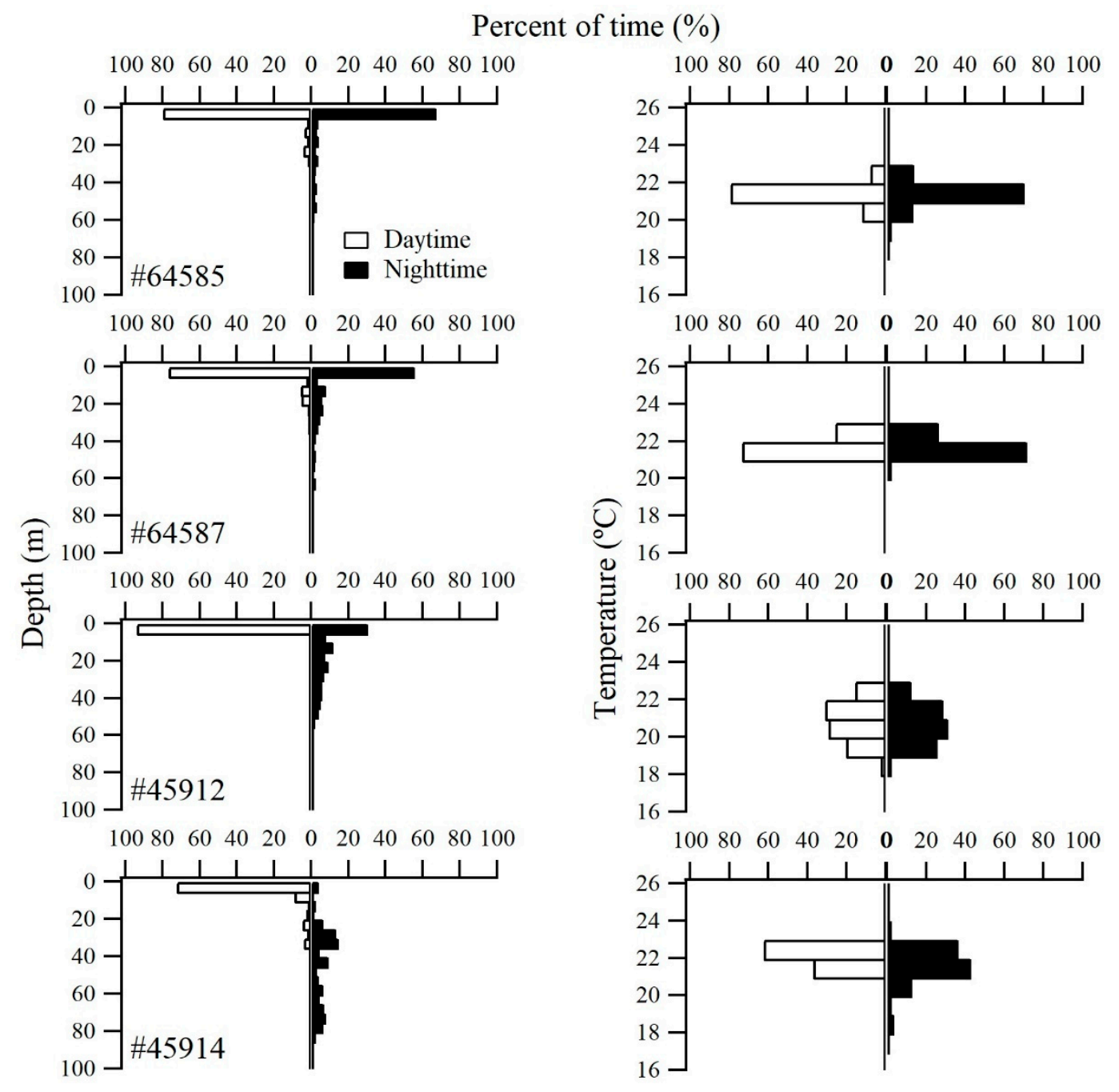

Figure 3. Depth and temperature histograms.

Cumulative percentage of the temperature readings expressed as $\triangle$ SST showed that tagged dolphinfish spent $>95 \%$ of movements within $3{ }^{\circ} \mathrm{C}$ of SST (Table 2). The aggregated temperature-depth profile indicates residency within the MLD (Figure 6). The cluster analysis (Figure 7) suggests a clinal trend in thermal clusters with limited movement or mixing among locations, but the tag retention times were too short to adequately test the assumption of mixing or population connectivity. 


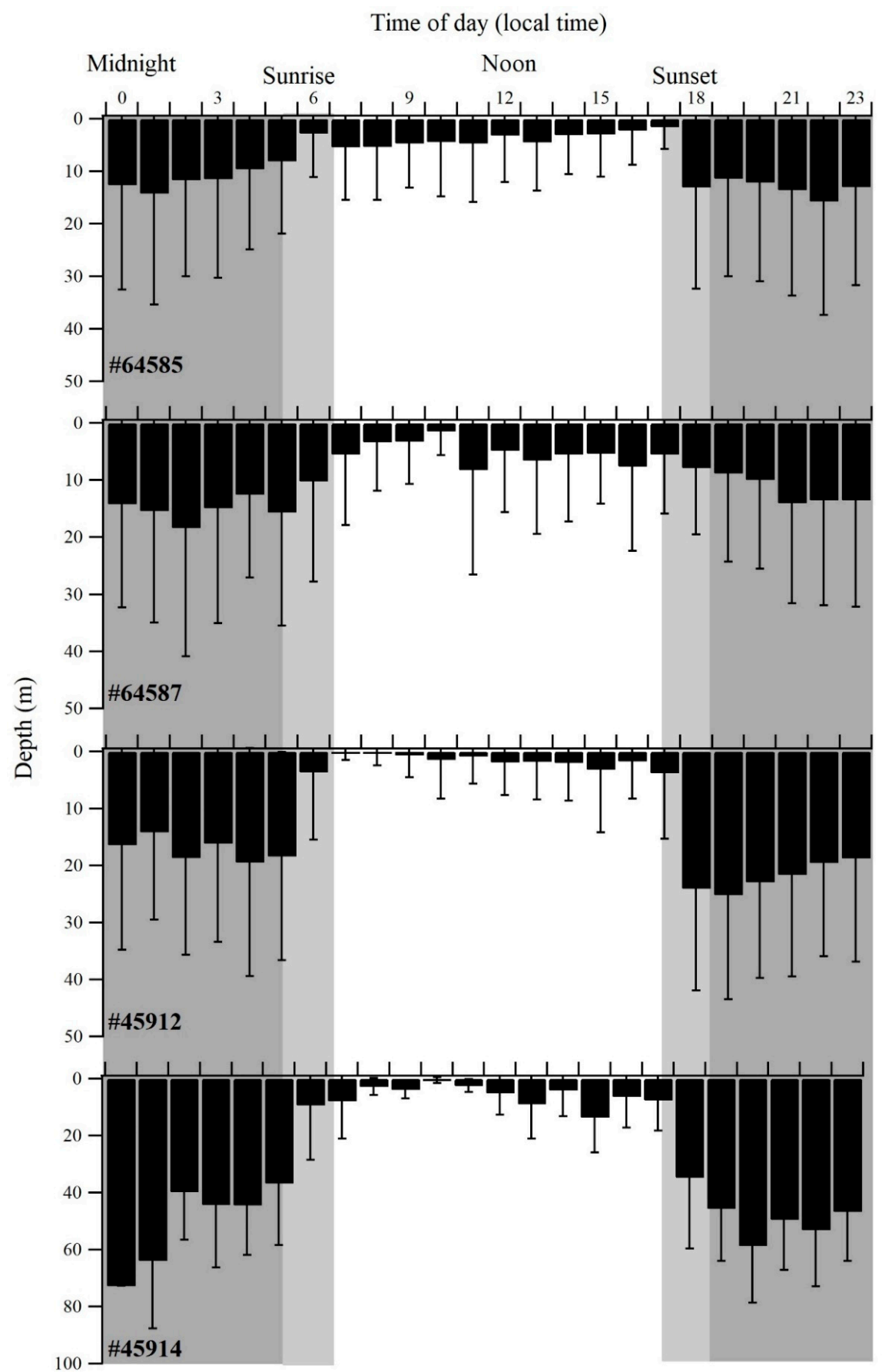

Figure 4. Average depth by time for dolphinfish (error bar is the standard deviation).
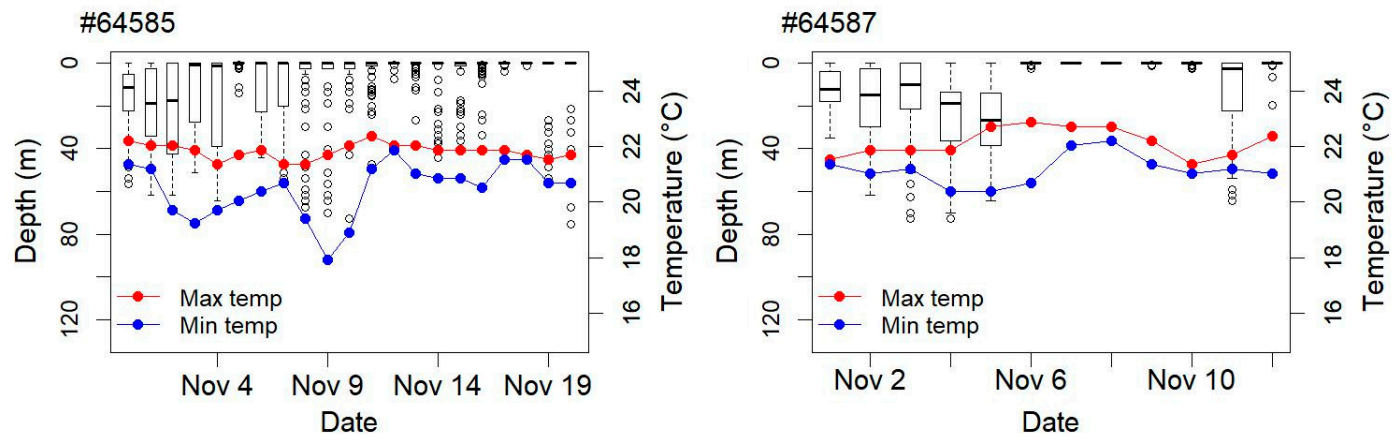

Figure 5. Cont. 

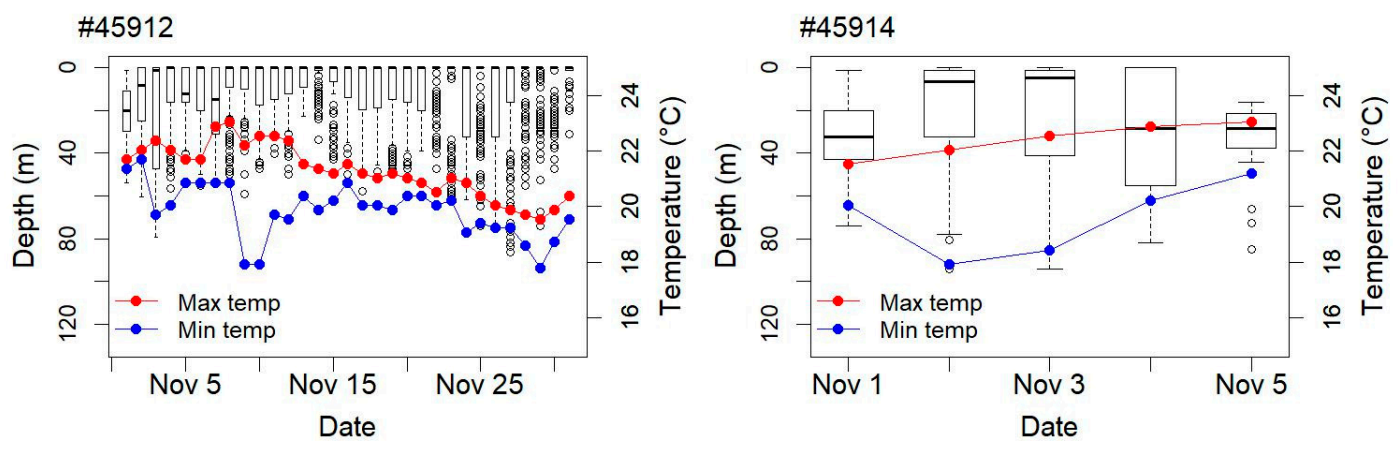

Figure 5. Minimum and maximum daily temperature (SST) and depths experienced by tagged dolphinfish. Boxplots represent the depths experienced by tagged dolphinfish.

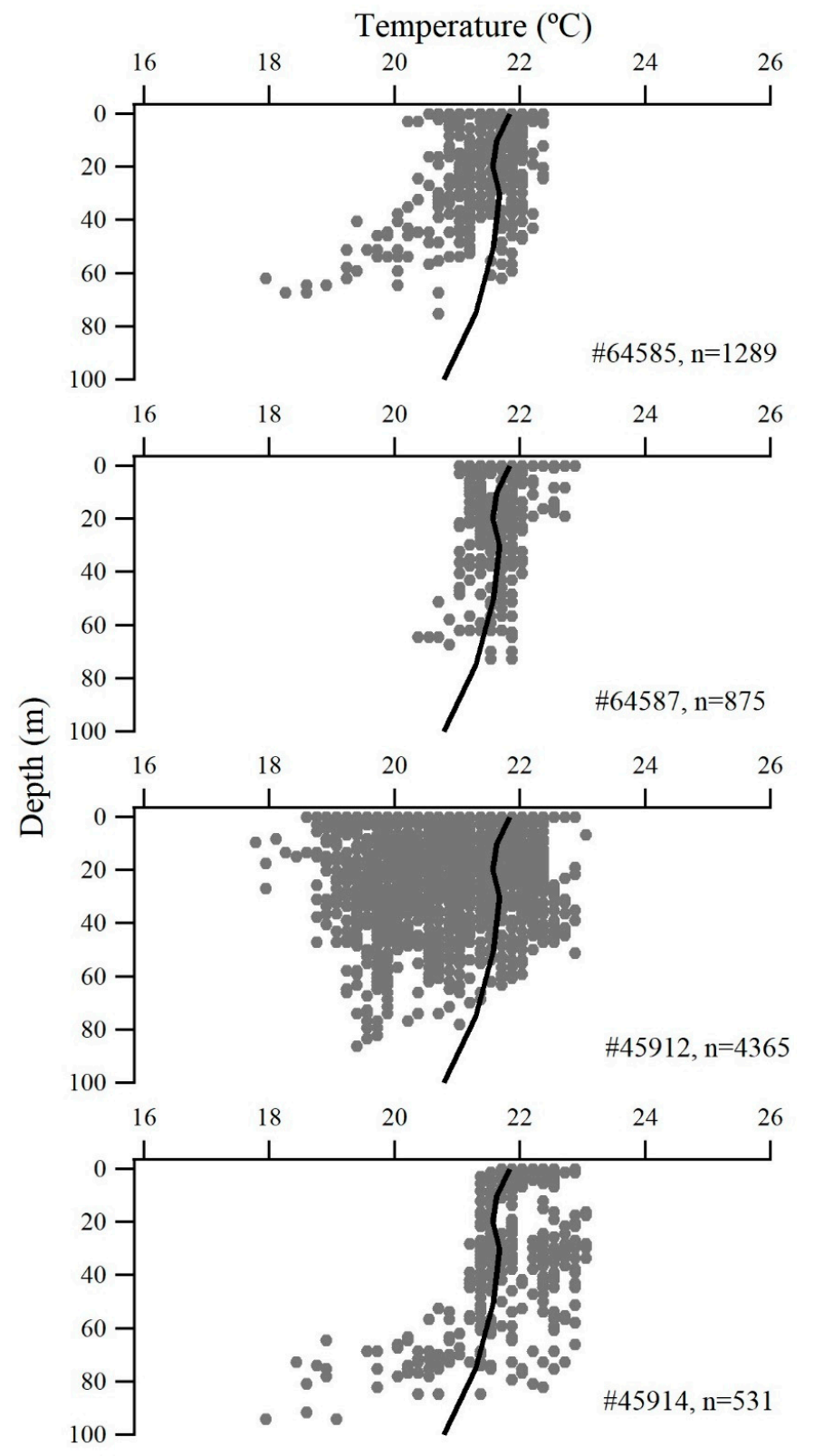

Figure 6. Temperature-depth profiles obtained from the aggregated data from dolphinfish tagged in the Northern East China Sea. Solid black lines represent the vertical temperature-depth profiles from APDRC data (Asia-Pacific Data Research Center, http://apdrc.soest.hawaii.edu/). The mixed-layer is $\sim 80-100 \mathrm{~m}$ depth and water temperature $20-22{ }^{\circ} \mathrm{C}$. 
Table 2. Cumulative percentage of temperature readings from PSATs attached to dolphinfish in the Northern East China Sea expressed as differences from daily calculated sea surface temperature $\Delta$ SST $\left({ }^{\circ} \mathrm{C}\right)$ by daytime and nighttime. PSATs\# 132762, 157954, 157963, 034331,163106, and 157958 were from data published in [26].

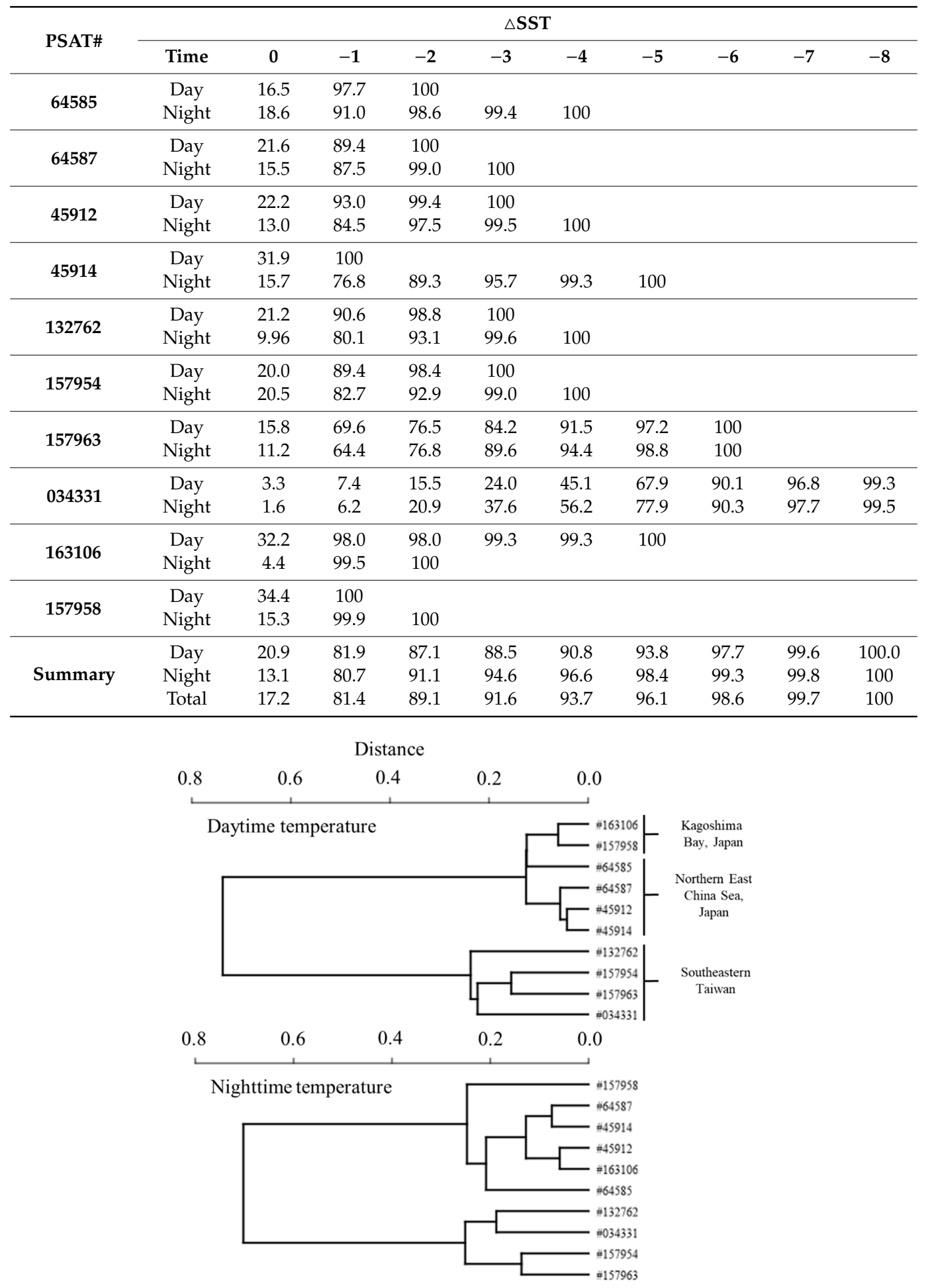

Figure 7. UPGMA (unweighted pair-group method using arithmetic averages) clustering using the Kolmogorov-Smirnov $\mathrm{D}_{\mathrm{N}}$ dissimilarity distance matrix among samples constructed from temperature data for dolphinfish in this study and a previous study [26]. Goodness-of-fit between the matrices and dendrograms was measured by the cophenetic correlation ( 0.965 for daytime; 0.936 for nighttime) with correlations $>0.9$ considered very good [28]. 


\section{Discussion}

This study provides new insights into the movement behavior of dolphinfish in the Northern East China Sea. To our knowledge, this is the first PSAT tagging experiment with dolphinfish from a coastal set-net fishery. Compared with other studies on dolphinfish $[25,26]$, we observed similar PSAT shedding $(\sim 80 \%)$ and retention rates [28]. In this study, dolphinfish were captured in set-nets and were considered large enough and in good condition to be PSAT tagged. The premature pop-ups in the study were from detached shed tags and were not indicative of post-release mortality. We checked to ensure that rigged PSATs (i.e., with tether and tag head attached) would float when shed to discriminate a dead sinking fish (with PSAT attached) from a shed, floating PSAT. Many factors are thought to explain premature pop-off in pelagic fishes and sharks affixed with PSATs, including infection and biofouling [28].

\subsection{Short-Term Movement Patterns}

In the Pacific Ocean, dolphinfish are found year-round within latitudes $30^{\circ}$ [35]. In the Sea of Japan, dolphinfish show seasonal movements from summer to autumn when they are targets of commercial fisheries [26]. Dolphinfish move southwards in early summer and northwards in early winter in Taiwan, in association with movements into warm water during autumn and winter, but this pattern was not found in this study. According to SSTs in the East China Sea in November 2018, temperatures in the PSATs largely paralleled the $20^{\circ} \mathrm{C}$ isotherm (Figure 1). In this study, we estimated dolphinfish spent $>80 \%$ of time above $20^{\circ} \mathrm{C}$ (Figure 8), which indicates cooler preferences compared to similar distribution patterns found in the Western Central Atlantic $\left(25-28^{\circ} \mathrm{C}\right)$, Gulf of California $\left(28-30^{\circ} \mathrm{C}\right)[10,25]$, and Southeastern Taiwan $\left(27-29^{\circ} \mathrm{C}\right)$ [26]. The preferred thermal habitat of dolphinfish was generally considered $>20^{\circ} \mathrm{C}$ in the Northern East China Sea [24], which corresponds favorably to our study. In the Northwest Pacific Ocean, the fishing grounds of dolphinfish are the Sea of Japan to the northeast of Taiwan during autumn and winter [17]. A prominent feature, the Tsushima Warm Current through the Tsushima Strait, flows northwards into the Sea of Japan from the East China Sea [36-39]. It is likely that dolphinfish near Tsushima Island move northwards with the Tsushima Warm Current. Based on foraging studies [40], adults feed mainly on pelagic fish in Japan, especially Japanese anchovy (Engraulis japonicus). On an annual basis, dominant cohorts of Japanese anchovy have been reported in the East China Sea in spring and autumn [24] and dolphinfish probably mirror movements of these recruits. This finding suggests that Japanese anchovy could influence dolphinfish residency patterns in the East China Sea.

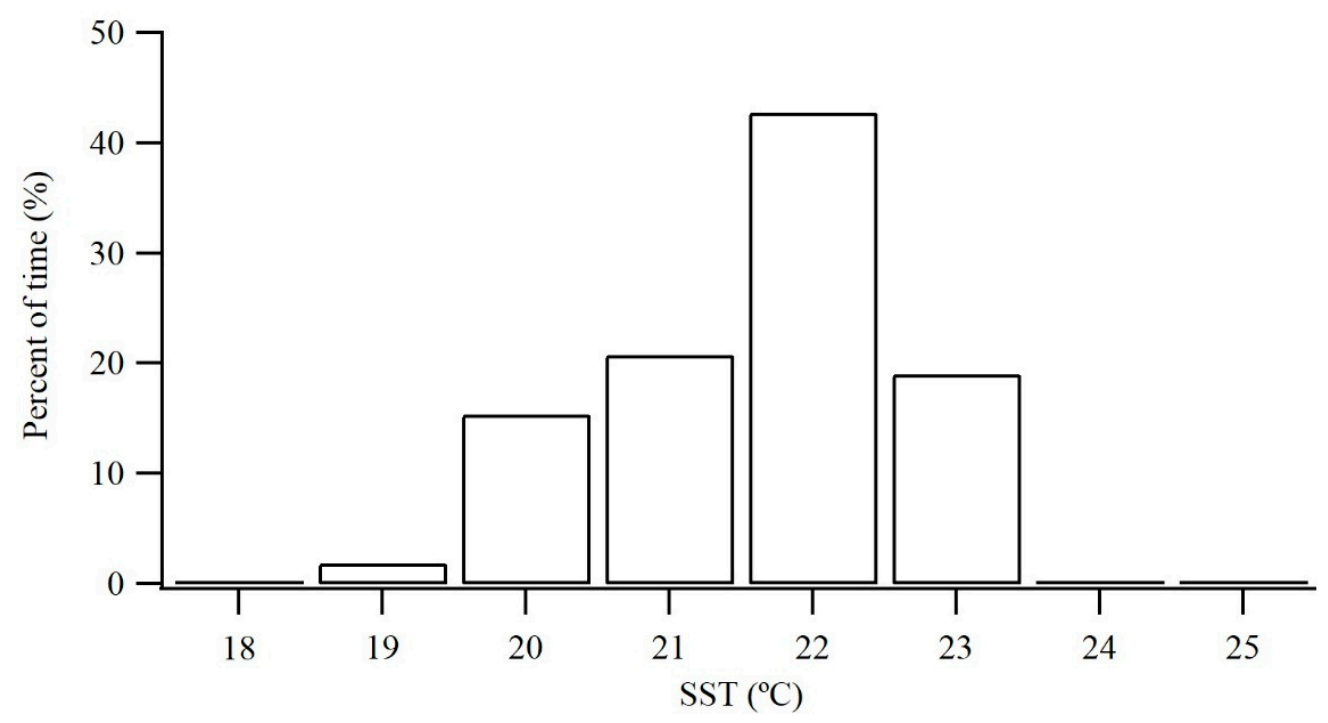

Figure 8. Histogram of aggregated sea surface temperature experienced by tagged dolphinfish in the Northern East China Sea. 


\subsection{Vertical Distribution}

Dolphinfish mainly occupied the uniform sea surface $(<5 \mathrm{~m})$ and exhibited significant differences in depth and temperature distributions between daytime and nighttime. More extensive vertical movements were made during nighttime rather than daytime, which corresponds with previous tagging studies using acoustic tags, electronic tags, and PSATs [23-26]. This diel pattern, however, is contrary to the behavior of large pelagic apex predators such as sharks, istiophorid billfish, bigeye tuna, and broadbill swordfish, which are characterized by deeper diving during daytime with shallow movements at nighttime [28,41-44].

The opposite diel patterns exhibited by dolphinfish compared to larger apex pelagic predators may reflect predator avoidance [26] and/or feeding preferences. As mainly visual predators, dolphinfish forage around the clock $[2,5,45]$ and tend to prefer environments with good visibility $[2,46]$. There is evidence to suggest that there are two cohorts of Japanese anchovy in the East China Sea during spring and autumn $[24,47]$ and during daytime, dolphinfish reside primarily at the surface to presumably forage on these resources. Studies have reported that changes in vertical movement patterns of large planktivores such as whale sharks [48], basking sharks [49], and piscivores such as porbeagle sharks [50] and great white sharks [51] are adaptable and can be altered to pursue vertically migrating prey. This plasticity in foraging behavior can be regarded as a shift in feeding strategy that increases prey encounters whilst minimizing energy expenditure $[24,27,48]$. Unfortunately, we did not analyze stomach contents to test these relationships, but diel vertical movement patterns varied according to time of day and likely reflect changes in prey distribution. Crepuscular dives are likely related to targeting aggregating prey organisms that adjust their own diel cycles based on ambient light, foraging, predator avoidance, and physiological limitations [44].

Ambient temperature is a critical factor affecting the vertical movement of dolphinfish $[12,24,26]$. In this study, dolphinfish occupied ambient temperatures within $3{ }^{\circ} \mathrm{C}$ of the warmest water available. However, comparable dolphinfish studies indicate different $\Delta$ SST patterns: Atlantic $\left(8^{\circ} \mathrm{C}\right)$, Eastern Taiwan $\left(6^{\circ} \mathrm{C}\right)$, and Kagoshima Bay, Japan $\left(2{ }^{\circ} \mathrm{C}\right)$ (Table 2$)$. Although dolphinfish exhibit the ability to experience a wide range of temperature changes, depth distributions in this study and others appeared to be limited by temperature gradients and occupancy in the mixed layer (Table 3). In the Atlantic, seasonal changes in the thermocline and oxycline have been shown to affect the vertical distribution of dolphinfish $[25,27,52,53]$. The Northern East China Sea is mostly continental shelf and is relatively shallow, but the vertical temperature structure changes seasonally [54] and mixing occurs from late autumn to spring [27] with a strong thermocline in late spring through summer. The mixing of different water masses with varied temperature gradients is one of the factors thought to affect the vertical movements of the dolphinfish [24], and the poleward expansion of dolphinfish in the Eastern Pacific Ocean [55]. The cluster analysis suggests a clinal trend of distinct thermal clusters with limited mixing among locations, but tag retention times were too short to test the hypothesis of mixing and connectivity. 
Table 3. Summary of the depth and temperatures obtained from different studies on dolphinfish.

\begin{tabular}{cccccccc}
\hline $\begin{array}{c}\text { Electronic } \\
\text { Device Type }\end{array}$ & Location & $\mathbf{N}$ & $\begin{array}{c}\text { Length } \\
\mathbf{( c m})\end{array}$ & $\begin{array}{c}\text { Days-at-Liberty } \\
\text { (Days) }\end{array}$ & $\begin{array}{c}\text { Max } \\
\text { Depth } \\
\text { Range } \mathbf{( m )}\end{array}$ & $\begin{array}{c}\text { Temperature } \\
\text { Range }\left({ }^{\circ} \mathbf{C}\right)\end{array}$ & Reference \\
\hline PSAT & $\begin{array}{c}\text { Northern East } \\
\text { China Sea }\end{array}$ & 4 & $94-102$ & $5-30$ & $59-94$ & $17.8-23.05$ & This study \\
\hline PSAT & $\begin{array}{c}\text { Southeastern } \\
\text { Taiwan }\end{array}$ & 4 & $99-113$ & $7-30$ & $40-89$ & $21.4-30.1$ & $\begin{array}{c}\text { Lin et al. } \\
(2019)[26]\end{array}$ \\
\hline PSAT & Kagoshima Bay & 2 & $81-84$ & $20-30$ & $24-99$ & $17.9-23.6$ & $\begin{array}{c}\text { Lin et al. } \\
(2019)[26]\end{array}$ \\
\hline PSAT & $\begin{array}{c}\text { Western Central } \\
\text { Atlantic }\end{array}$ & 6 & $97.5-120$ & $4-30$ & $74-255.5$ & $16-30$ & $\begin{array}{c}\text { Merten et al. } \\
(2014)[25]\end{array}$ \\
\hline Archival tag & $\begin{array}{c}\text { Southeastern } \\
\text { Taiwan }\end{array}$ & 2 & $54-73$ & $3-9$ & $54.1-62.7$ & $19.0-27.9$ & $\begin{array}{c}\text { Furukawa et al. } \\
(2015)[56]\end{array}$ \\
\hline $\begin{array}{c}\text { Acceleration } \\
\text { data-logger }\end{array}$ & $\begin{array}{c}\text { Northern East } \\
\text { China Sea }\end{array}$ & 8 & $67-90$ & $3-47 *$ & $53.1-95.4$ & $18.5-28.4$ & $\begin{array}{c}\text { Furukawa et al. } \\
(2011)[56]\end{array}$ \\
\hline
\end{tabular}

\subsection{Future Research and Management}

General inferences into the vertical movements of dolphinfish in the Northern East China Sea were presented, which will be particularly useful for management. The horizontal and vertical movement behaviors of dolphinfish provide fishery-independent information to inform stock assessments in Taiwan [21]. Due to similarities in the vertical extent of their habitat, dolphinfish in Southeastern Taiwan and Northern East China Sea appeared to utilize similar habitats and were hypothesized to comprise the same stock [20]. To understand the connectivity and linkages of dolphinfish between Japan and Taiwan, additional research is required to further correlate and validate movement patterns over larger time scales. One of the major outputs provided by PSATs to inform fishery management is the extent of the preferred habitat and habitat utilization patterns, which form an essential component of plans to improve and protect fishery resources. With information on vertical movement patterns, alterations to the depth of fishing gears and deployment times could be made to mismatch diving patterns and susceptibility to fishing gears in order to decrease dolphinfish by-catch. Results from this study were hampered by small sample sizes and, because only large dolphinfish were tagged, results may not be indicative of younger and juvenile dolphinfish. Future research should target different age and size classes with conventional and smaller implantable archival tags to better define the vertical and thermal niche and changes in habitat use to understand population connectivity and movement corridors.

Author Contributions: All authors contributed to this study. Conceptualization, methodology, and investigation W.-C.C., M.K.M., S.-P.W., N.-J.S., and R.K.; data analysis, visualization, and writing (original draft preparation) S.-J.L., W.-C.C., M.K.M., S.-P.W., N.-J.S., Q.-X.C., Y.-S.H., I.N., C.-T.T., and R.K.; resources R.K., I.N., and C.-T.T. All authors have read and agreed to the published version of the manuscript.

Funding: This study was partially funded by the Fisheries Research Institute, council to Agriculture, Taiwan [grant nos. 107AS-9.2.2-A1(2) and 108AS-9.2.2-A1(5)].

Acknowledgments: We are thankful for the support from the Tachiura Fisheries Cooperative Association. We also thank fishing master Fujinaga Masayuki and crewmembers of the set-net complex for their help in tagging dolphinfish.

Conflicts of Interest: The named authors have no conflicts of interest, financial or otherwise.

\section{References}

1. Vladykov, V.D.; McKenzie, R.A. The marine fishes of Nova Scotia. Proc. Nova Scotian Inst. Sci. 1935, 19, 17-113.

2. Shcherbachev, Y.N. The biology and distribution of the dolphins (Pisces, Coryphaenidae). J. Ichthyol. 1973, 13, 182-191. 
3. Palko, B.J.; Beardsley, G.L.; Richards, W.J. Synopsis of biological data on dolphin-fishes, Coryphaena hippurus Linnaeus and Coryphaena equiselis Linnaeus. FAO Fish. Synop. 1982, 130, 1-28.

4. Norton, J.G. Apparent habitat extensions of dolphinfish (Coryphaena hippurus) in response to climate transients in the California Current. Sci. Mar. 1999, 63, 239-260. [CrossRef]

5. Oxenford, H.A.; Hunte, W. Feeding habits of the dolphinfish (Coryphaena hippurus) in the eastern Caribbean. Sci. Mar. 1999, 63, 303-315. [CrossRef]

6. Rivera, G.A.; Appeldoorn, R.S. Age and growth of dolphinfish, Coryphaena hippurus, off Puerto Rico. Fish. Bull. 2000, 98, 345-352.

7. Alejo-Plata, C.; Díaz-Jaimes, P.; Salgado-Ugarte, I.H. Sex ratios, size at sexual maturity, and spawning seasonality of dolphinfish (Coryphaena hippurus) captured in the Gulf of Tehuantepec, Mexico. Fish. Res. 2011, 110, 207-216. [CrossRef]

8. Farrell, E.R.; Boustany, A.M.; Halpin, P.N.; Hammond, D.L. Dolphinfish (Coryphaena hippurus) distribution in relation to biophysical ocean conditions in the northwest Atlantic. Fish. Res. 2014, 151, 177-190. [CrossRef]

9. Kraul, S. Seasonal abundance of dolphinfish, Coryphaena hippurus, in Hawaii and the tropical Pacific Ocean. Sci. Mar. 1999, 63, 261-266. [CrossRef]

10. Zúñiga-Flores, M.S.; Ortega-García, S.; Klett-Trauslen, A. Interannual and seasonal variation of dolphinfish (Coryphaena hippurus) catch rates in the southern Gulf of California, Mexico. Fish. Res. 2008, 94, 13-17. [CrossRef]

11. Schwenke, K.L.; Buckel, J.A. Age, growth, and reproduction of dolphinfish (Coryphaena hippurus) caught off the coast of North Carolina. Fish. Bull. 2008, 106, 82-92.

12. Torrejón-Magallanes, J.; Grados, D.; Lau-Medrano, W. Spatio-temporal distribution modeling of dolphinfish (Coryphaena hippurus) in the Pacific Ocean off Peru using artisanal longline fishery data. Deep-Sea Res. Part II 2019, 169-170, 104665. [CrossRef]

13. Furukawa, S.; Ohshimo, S.; Tomoe, S.; Shiraishi, T.; Nakatsuka, N.; Kawabe, R. Age, growth, and reproductive characteristics of dolphinfish Coryphaena hippurus in the waters off west Kyushu, northern East China Sea. Fish. Sci. 2012, 78, 1153-1162. [CrossRef]

14. Trippel, E.A. Age at maturity as a stress indicator in fisheries. BioScience 1995, 45, 759-771. [CrossRef]

15. Beardsley, G.L., Jr. Age, growth and reproduction of the dolphin, Coryphaena hippurus, in the Straits of Florida. Copeia 1967, 1967, 441-451. [CrossRef]

16. Rodriguez-Ferrer, G.; Rodriguez-Ferrer, Y.; Matos-Caraballo, D.; Yestrom, C.L. Comparison of dolphinfish (Coryphaena hippurus) commercial and recreational fisheries in Puerto Rico during 2000-2003. Proc. Gulf Caribb. Fish. Inst. 2004, 57, 297-316.

17. Sakamoto, R.; Kojima, S. Review of dolphinfish biological and fishing data in Japanese waters. Sci. Mar. 1999, 63, 375-385. [CrossRef]

18. Díaz-Jaimes, P.; Uribe-Alcocer, M.; Ortega-García, S.; Durand, J.D. Spatial and temporal mitochondrial DNA genetic homogeneity of dolphinfish populations (Coryphaena hippurus) in the eastern central Pacific. Fish. Res. 2006, 80, 333-338. [CrossRef]

19. Tripp-Valdez, M.A.; de García León, F.J.; Ortega-García, S.; Lluch-Cota, D.; López-Martínez, J.; Cruz, P. Population genetic structure of dolphinfish (Coryphaena hippurus) in the Gulf of California, using microsatellite loci. Fish. Res. 2010, 105, 172-177. [CrossRef]

20. Chang, S.K.; DiNardo, G.; Farley, J.; Brodziak, J.; Yuan, Z.L. Possible stock structure of dolphinfish (Coryphaena hippurus) in Taiwan coastal waters and globally based on reviews of growth parameters. Fish. Res. 2013, 147, 127-136. [CrossRef]

21. SFP Urges Stock-Wide Assessments of Pacific Mahi in First Sustainability Overiew Report. Available online: https://www.sustainablefish.org/News/SFP-Urges-Stock-Wide-Assessments-of-Pacific-Mahi-inFirst-Sustainability-Overview-Report (accessed on 28 March 2020).

22. Chang, S.K.; Yuan, T.L.; Wang, S.P.; Chang, Y.J.; DiNardo, G. Deriving a statistically reliable abundance index from landings data: An application to the Taiwanese coastal dolphinfish fishery with a multispecies feature. Trans. Am. Fish. Soc. 2019, 148, 106-122. [CrossRef]

23. Whitney, N.M.; Taquet, M.; Brill, R.W.; Girard, C.; Schwieterman, G.D.; Dagorn, L.; Holland, K.N. Swimming depth of dolphinfish (Coryphaena hippurus) associated and unassociated with fish aggregating devices. Fish. Bull. 2016, 114, 426-434. [CrossRef] 
24. Furukawa, S.; Kawabe, R.; Ohshimo, S.; Fujioka, K.; Nishihara, G.N.; Tsuda, Y.; Aoshima, T.; Kanehara, H. Vertical movement of dolphinfish Coryphaena hippurus as recorded by acceleration data-loggers in the northern East China Sea. Environ. Biol. Fish. 2011, 92, 89-99. [CrossRef]

25. Merten, W.; Appeldoorn, R.; Rivera, R.; Hammond, D. Diel vertical movements of adult male dolphinfish (Coryphaena hippurus) in the western central Atlantic as determined by use of pop-up satellite archival transmitters. Mar. Biol. 2014, 161, 1823-1834. [CrossRef]

26. Lin, S.J.; Musyl, M.K.; Wang, S.P.; Su, N.J.; Chiang, W.C.; Lu, C.P.; Tone, K.; Wu, C.Y.; Sasaki, A.; Nakamura, I.; et al. Movement behaviour of released wild and farm-raised dolphinfish, Coryphaena hippurus, tracked by pop-up satellite archival tags. Fish. Sci. 2019, 85, 779-790. [CrossRef]

27. Furukawa, S.; Tsuda, Y.; Nishihara, G.N.; Fujioka, K.; Ohshimo, S.; Tomoe, S.; Nakatsuka, N.; Kimura, H.; Aoshima, T.; Kanehara, H.; et al. Vertical movements of Pacific bluefin tuna (Thunnus orientalis) and dolphinfish (Coryphaena hippurus) relative to the thermocline in the northern East China Sea. Fish. Res. 2014, 149, 86-91. [CrossRef]

28. Musyl, M.K.; Brill, R.W.; Curran, D.S.; Fragoso, N.M.; McNaughton, L.M.; Nielsen, A.; Kikkawa, B.S.; Moyes, C.D. Postrelease survival, vertical and horizontal movements, and thermal habitats of five species of pelagic sharks in the central Pacific Ocean. Fish. Bull. 2011, 109, 341-368.

29. Musyl, M.K.; Domeier, M.L.; Nasby-Lucas, N.; Brill, R.W.; McNaughton, L.M.; Swimmer, J.Y.; Lutcavage, M.S.; Wilson, S.G.; Galuardi, B.; Liddle, J.B. Performance of pop-up satellite archival tags. Mar. Ecol. Prog. Ser. 2011, 433, 1-28. [CrossRef]

30. Lam, C.H.; Nielsen, A.; Sibert, J.R. Improving light and temperature based geolocation by unscented Kalman filtering. Fish. Res. 2008, 91, 15-25. [CrossRef]

31. Lam, C.H.; Nielsen, A.; Sibert, J.R. Incorporating sea-surface temperature to the light-based geolocation model TrackIt. Mar. Ecol. Prog. Ser. 2010, 419, 71-84. [CrossRef]

32. Zar, J.H. Biostatistical Analysis, 5th ed.; Prentice Hall: Upper Saddle River, NJ, USA, 2010.

33. Brill, R.W.; Holts, D.B.; Chang, R.K.C.; Sullivan, S.; Dewar, H.; Carey, F.G. Vertical and horizontal movements of striped marlin (Tetrapturus audax) near the Hawaiian Islands, determined by ultrasonic telemetry, with simultaneous measurement of oceanic currents. Mar. Biol. 1993, 117, 567-574. [CrossRef]

34. Nielsen, A.; Bigelow, K.A.; Musyl, M.K.; Sibert, J.R. Improving light-based geolocation by including sea surface temperature. Fish. Oceanogr. 2006, 15, 314-325. [CrossRef]

35. Kojima, S. On the distribution of the dolphin, Coryphaena hippurus L., in the Pacific Ocean and the Indian Ocean. Bull. Jpn. Soc. Sci. Fish. 1964, 30, 472-477. [CrossRef]

36. Toba, Y.; Tomizawa, K.; Kurasawa, Y.; Hanawa, K. Seasonal and year-to-year variability of the Tsushima-Tsugaru current systrm with its possible cause. La Mer 1982, 20, 41-51.

37. Ohshima, K.I. The flow system in the Japan sea caused by a sea level difference through shallow straits. J. Geophys. Res. 1994, 99, 9925-9940. [CrossRef]

38. Takikawa, T.; Yoon, J.H.; Cho, K.D. The Tsushima warm current through Tsushima straits estimated from ferryboat ASCP data. J. Phys. Oceanogr. 2005, 35, 1154-1168. [CrossRef]

39. Watanabe, T.; Katoh, O.; Yamada, H. Structure of the Tsushima Warm Current in the Northeastern Japan Sea. J. Oceanogr. 2006, 62, 527-538. [CrossRef]

40. Kojima, S. Studies on fishing conditions of the dolphin, Coryphaena hippurus, in the western regions of the Sea of Japan-XI. School of dolphins accompanying various kinds of flotages. Bull. Jpn. Soc. Sci. Fish. 1966, 32, 647-651. [CrossRef]

41. Carey, F.G.; Scharold, J.V.; Kalmijn, A.J. Movements of blue sharks (Prionace glauca) in depth and course. Mar. Biol. 1990, 106, 329-342. [CrossRef]

42. Holland, K.; Brill, R.; Chang, R.K.C. Horizontal and vertical movements of Pacific blue marlin captured and released using sportfishing gear. Fish. Bull. 1990, 88, 397-402.

43. Block, B.A.; Booth, D.T.; Carey, F.G. Depth and temperature of the blue marlin, Makaira nigricans, observed by acoustic telemetry. Mar. Biol. 1992, 114, 175-183. [CrossRef]

44. Musyl, M.K.; Brill, R.W.; Boggs, C.H.; Curran, D.S.; Kazama, T.K.; Seki, M.P. Vertical movements of bigeye tuna (Thunnus obesus) associated with islands, buoys, and seamounts near the main Hawaiian Islands from archival tagging data. Fish. Oceanogr. 2003, 12, 152-169. [CrossRef]

45. Massuti, E.; Deudero, S.; Sanchez, P.; Morales-Nin, B. Diet and feeding of dolphin (Coryphaena hippurus) in western Mediterranean waters. Bull. Mar. Sci. 1998, 63, 329-341. 
46. Rothschild, R.J. Observations on dolphins (Coryphaena spp.) in the central Pacific Ocean. Copeia 1964, 1964, 375-385. [CrossRef]

47. Wang, Y.C.; Chen, W.Y.; Chen, Y.K.; Kuo, Y.C.; Lee, M.A. Winter abundance and species composition of anchovy larvae associated with hydrological conditions in the coastal waers of Tanshul, Taiwan. J. Mar. Sci. Technol. 2018, 26, 455-474. [CrossRef]

48. Gleiss, A.C.; Wright, S.; Liebsch, N.; Wilson, R.P.; Norman, B. Contrasting diel patterns in vertical movement and locomotor activity of whale sharks at Ningaloo Reef. Mar. Biol. 2013, 160, 2981-2992. [CrossRef]

49. Sims, D.W.; Southall, E.J.; Tarling, G.A.; Metcalfe, J.D. Habitat-specific normal and reverse diel vertical migration in the plankton feeding basking shark. J. Anim. Ecol. 2005, 74, 755-761. [CrossRef]

50. Saunders, R.A.; Royer, F.; Clarke, M.W. Winter migration and diving behavior of porbeagle shark, Lamna nasus, in the northeast Atlantic. ICES J. Mar. Sci. 2011, 68, 166-174. [CrossRef]

51. Weng, K.C.; Boustany, A.M.; Pyle, P.; Anderson, S.C.; Brown, A.; Block, B.A. Migration and habitat of white sharks (Carcharodon carcharias) in the eastern Pacific Ocean. Mar. Biol. 2007, 152, 877-894. [CrossRef]

52. Stramma, L.; Prince, E.D.; Schmidtko, S.; Luo, J.; Hoolihan, J.P.; Visbeck, M.; Wallace, D.W.R.; Brandt, P.; Kortzinger, A. Expansion of oxygen minimum zones may reduce available habitat for tropical pelagic fishes. Nat. Clim. Chang. 2012, 2, 33-37. [CrossRef]

53. Prince, E.D.; Lou, J.; Goodyear, C.P.; Hoolihan, J.P.; Snodgrass, D.; Orbesen, E.S.; Serafy, J.E.; Ortiz, M.; Schirripa, M.J. Ocean scale hypoxiabased habitat compression of Atlantic istiophorid billfishes. Fish. Oceanogr. 2010, 19, 448-462. [CrossRef]

54. Val, A.L.; Almeida-Val, V.M.F.; Randall, D.J. Fish Physiology. In The Physiology of Tropical Fishes; Elsevier/Academic Press: London, UK, 2006; Volume 21.

55. Salvadeo, C.; Auliz-Ortiz, D.M.; Petatán-Ramírez, D.; Reyes-Bonilla, H.; Ivanova-Bonchera, A.; Juárez-León, E. Potential poleward distribution shift of dolphinfish (Coryphaena hippurus) along the southern California Current System. Environ. Biol. Fish. 2020, 103, 973-984. [CrossRef]

56. Furukawa, S.; Chiang, W.C.; Watanabe, S.; Hung, H.M.; Lin, H.C.; Yeh, H.M.; Wang, S.P.; Tone, K.; Kawabe, R. The first record of peritoneal cavity temperature in free-swimming dolphinfish Coryphaena hippurus by using archival tags, on the East Coast of Taiwan. J. Aquacult. Mar. Biol. 2015, 2, 1-7. [CrossRef] 